\title{
Effect of the test media and toxicity of LAS on the growth of Isochrysis galbana
}

\author{
M. C. Garrido-Perez · J. A. Perales-VargasMachuca • \\ E. Nebot-Sanz · D. Sales-Márquez
}

Accepted: 28 April 2008/Published online: 13 May 2008

(C) Springer Science+Business Media, LLC 2008

\begin{abstract}
In this paper, the toxicity of linear alkylbenzene sulfonate (LAS) was evaluated in the marine microalga Isochrysis galbana using data of growth inhibition toxicity tests at 96-h exposure time. Toxicity was examined in standard conditions and by means of the modification of two variables of the test media: (1) the dilution water and (2) the content of nutrients in the test medium. For this purpose, a total of 10 toxicity test were designed: five dilution waters, four natural marine waters and one synthetic seawater; each in two different nutritive conditions, saturated nutrient concentration (SC) by the addition of modified $\mathrm{f} / 2$ nutritive medium, and natural nutrient concentration (NC), i.e., without the addition of $f / 2$. At threshold toxicity levels, the dilution waters used in the test and the nutrient concentrations did not affect the toxicity of LAS. At $\mathrm{IC}_{50}$ concentrations, the toxicity of LAS is influenced by both variables: under SC conditions, the toxic effect of LAS diminishes, obtaining in all the tests $\mathrm{IC}_{50}>10 \mathrm{mg} / \mathrm{L}$ LAS. Under NC conditions, $\mathrm{IC}_{50}$ concentrations ranging between 3.15 and $9.26 \mathrm{mg} / \mathrm{L}$ LAS have been obtained.
\end{abstract}

Keywords Surfactant - Linear alkylbenzene sulfonate (LAS) - Toxicity test $\cdot$ Microalga I Isochrysis galbana . $\mathrm{IC}_{50} \cdot$ Nutrient conditions

M. C. Garrido-Perez $(\bowtie) \cdot$ J. A. Perales-VargasMachuca .

E. Nebot-Sanz · D. Sales-Márquez

Department of Chemical Engineering, Food Technologies and Environmental Technologies, Faculty of Marine and Environmental Sciences, University of Cadiz, Pol. Río San Pedro s/n, 11510 Puerto Real, Cadiz, Spain

e-mail: carmen.garrido@uca.es

\section{Introduction}

The xenobiotic chemicals that reach the coasts through either punctual or diffuse sources of pollution can cause important inhibitory effects on the growth, reproduction and other physiological functions of the biological communities. Determining the toxicity of these chemicals and the environmental variables that modify the thresholds of toxicity is fundamental for developing tools for the management and protection of aquatic ecosystems (Rand 1995; ECETOC 2001).

At present, linear alkylbenzene sulfonates (LAS) is the most widely manufactured and consumed surfactant (Roberts 2003). Estimated world LAS consumption in 2000 was around 2.5 million tons (Sanz et al. 2003) and the use of surfactants will likely increase in the years to come (Cavalli et al. 1999). Due to its widespread use, discharges of wastewaters to natural waters contain important loads of these compounds (León et al. 2002; Ying 2006; González et al. 2007). The monitoring of surfactants in continental and marine waters has been the subject of numerous researches in the last years (Matthijs et al. 1999; Cavalli et al. 2000; Leon et al. 2002; LaraMartin et al. 2006). Regarding the effects of the LAS in aquatic organisms, there are numerous toxicity studies on freshwater species; see revisions in ECETOC (1993), Ramamoorthy and Baddaloo (1995), Rand (1995) and HERA (2004). However, information on marine organism is scarce, and in most of the published works, tests were carried out in standard and controlled experimental conditions, differing from those that we usually find in environmental waters.

In the marine environment, the unicellular planktonic algae are very important components of the biological communities. The importance of algal toxicity data has 
been recognized internationally. At this moment, there are numerous test guidelines published and incorporated in various regulatory procedures. Standardised tests of toxicity with microalgae are usually static tests, in which the algae are cultivated and exposed to different concentrations of a toxic chemical under controlled conditions of light and temperature.

In seawater tests, the medium is usually synthetic seawater enriched with salts, macro and micronutrients and vitamins up to non-limiting (saturated) concentrations. However, the seawater and nutritive formulations used in those tests are not representative of the natural marine environment. Coastal waters are considerably different from continental waters, from other adjacent coastal waters, and from oceanic waters, with regard to the concentrations of nutrients and organic and inorganic compounds. The concentrations of these compounds depend on their proximity to estuaries, direct discharges to the sea, local maritime traffic, the morphology of the zone, and the water exchange capacity (ECETOC 2001). In any case, the concentrations of nutritive elements are very much lower than those provided in any synthetic formulation for algal toxicity test. If toxicity tests are carried out in order to study the effects of chemicals on phytoplanktonic communities, the extrapolations of the results obtained under different conditions to those of the natural environment could be wrong.

The present work has been designed with the aim of studying the toxicity of LAS on the growth of Isochrysis galbana. With this objective, we have studied the effect of both types, saline matrix or dilution water and nutrient concentrations in the test media on the toxicity of the LAS.

\section{Material and methods}

\section{Chemical tested}

The chemical tested was a commercial mixture of homologues (C10-C13) and isomers of the sodium salt of dodecylbenzenesulfonate acid (LAS) (Supplier: Fluka Chemie A.G; Product $\mathrm{N}^{\circ}$ : 44200). The compound was tested in the following concentrations of $2,4,6,8$ and $10 \mathrm{mg} / \mathrm{L}$. Dissolutions of LAS were constructed using five different dilutions waters (Table 1).

Algal culture and test inoculum

Isochrysis galbana is an alga of the Haptophyceae class, found all over the world. In recent years it has been one of the most used marine microalgae in toxicity tests (MorenoGarrido et al. 2000; Hampel et al. 2001; Tsvetnenko and Evans, 2002; Garrido-Pérez et al. 2003; Tzovenis et al.
2004; Weiner et al. 2004; Yap et al. 2004; Satoh et al. 2005; Campa-Córdova et al. 2006; Correa-Reyes et al. 2007).

The source of the monocultures of I. galbana used in the toxicity tests was the Collection of Marine Microalgae Cultures of the Institute of Marine Sciences of Andalusia (Lubián and Yufera 1989).

The inoculum of I. galbana was cultivated under aseptic conditions in a nutritive medium composed of a synthetic seawater (USEPA 2002) and a supply of nutrients and vitamins according to the $f / 2$ nutritive medium (Guillard and Ryther 1962) modified with double nitrate and phosphate concentrations (Huertas et al. 2000) and silicate $\left(250 \mu \mathrm{g} / \mathrm{L} \mathrm{SiO}_{2}\right)$. Both the preculture and the tests were performed in an incubation chamber under controlled conditions of continuous illumination (cold white light of 11000 lux $)$ and temperature $\left(20 \pm 1{ }^{\circ} \mathrm{C}\right)$. The aeration to facilitate the exchange of gases was performed by means of manual shaking twice a day. Once the exponential phase of growth was reached (7-10 incubation days), the test inoculum was concentrated. For this, the culture was centrifuged at $2,000 \mathrm{~g}$ for $15 \mathrm{~min}$. The concentrate of cells obtained was resuspended in synthetic seawater and this operation was repeated until an inoculum in synthetic seawater free of nutrients was obtained (USEPA 2002).

\section{Experimental design}

A total of ten different toxicity tests have been performed: five dilution waters, -one synthetic seawater and four natural waters-, each one in two different nutritive conditions - saturated nutrient concentration (SC) by the addition of modified $\mathrm{f} / 2$, and natural nutritive concentration (NC), that is, without the addition of $\mathrm{f} / 2-$. Table 1 show the codes of each test. SSW $*$ is the test carried out in standard conditions with regard to dilution water (synthetic seawater) and the availability of nutrients (saturated condition).

The experimental protocol of the tests is according the method 1003.0 for measuring the toxicity of effluents and receiving waters with the microalga Selenastrum capricornotum (USEPA, 2002). The tests were performed in transparent and sterilised vials of borosilicate glass of $15 \mathrm{~mL}$ capacity. To allow the exchange of gases and to avoid external contamination, the vials were sealed with aluminium capsules. Volumes of $4 \mathrm{~mL}$ of test concentrations, and 100 microlitres of concentrated algae inoculum (with a cell concentration enough to ensure initial exponential growth) were added into each test vial. Each concentration or "treatment" and controls were tested in triplicate. 
Table 1 Test codes and concentration of nutrients in (a) NC test, (b) SC test

(a)

\begin{tabular}{llllrr}
\hline Elements/Test code & SSW & H & C & I \\
& Synthetic seawater & Huelva Estuary & Al Cadiz & $\begin{array}{l}\text { Al River } \\
\text { Bay of Algeciras }\end{array}$ \\
\hline C $(\mathrm{mg} / \mathrm{L})$ & 24.306 & 27.450 & 31.170 & 44.030 & 30.210 \\
$\mathrm{~N}(\mathrm{mg} / \mathrm{L})$ & $<0.010$ & 0.172 & 0.109 & 2.402 & 0.302 \\
$\mathrm{P}(\mathrm{mg} / \mathrm{L})$ & $<0.002$ & 0.057 & 0.013 & 0.463 & $<0.002$ \\
$\mathrm{Si}(\mathrm{mg} / \mathrm{L})$ & $<0.020$ & 0.046 & 0.120 & 0.372 & 0.070
\end{tabular}

(b)

\begin{tabular}{|c|c|c|c|c|c|}
\hline Elements/Test code & $\begin{array}{l}\mathrm{SSW}^{*} \\
\text { Synthetic seawater }+\mathrm{f} / 2\end{array}$ & $\begin{array}{l}\mathrm{H}^{*} \\
\text { Estuary of Huelva }+\mathrm{f} / 2\end{array}$ & $\begin{array}{l}\mathrm{C}^{*} \\
\text { Bay of Cadiz }+\mathrm{f} / 2\end{array}$ & $\begin{array}{l}\text { I* } \\
\text { Rio Iro }+\mathrm{f} / 2\end{array}$ & $\begin{array}{l}\mathrm{Al} * \\
\text { Bay of Algeciras }+f / 2\end{array}$ \\
\hline $\mathrm{C}(\mathrm{mg} / \mathrm{L})$ & 24.306 & 27.450 & 31.170 & 44.030 & 30.210 \\
\hline $\mathrm{N}(\mathrm{mg} / \mathrm{L})$ & 24.724 & 24.896 & 24.833 & 27.126 & 25.026 \\
\hline $\mathrm{P}(\mathrm{mg} / \mathrm{L})$ & 1.985 & 2.042 & 1.998 & 2.448 & 1.985 \\
\hline $\mathrm{Si}(\mathrm{mg} / \mathrm{L})$ & 0.117 & 0.163 & 0.237 & 0.489 & 0.187 \\
\hline
\end{tabular}

\section{Dilution seawaters}

Five different saline dilution waters were used in this work: one synthetic seawater from USEPA formulation (USEPA 2002) and four natural waters collected along the coast of Gulf of Cadiz (Southern Spain) (Fig. 1). In the selected littoral area, three great industrial and urban areas are located: Huelva Estuary, Bay of Cadiz, and Bay of Algeciras (Table 2). For several decades, the industrial and urban effluent discharges from these areas have had a direct impact on those coasts, adversely affecting the quality of the waters. The fourth location is the estuary of the Iro River, integrated in a system of salt marshes of high ecological value in the inner lands of the Bay of Cadiz. This estuary is strongly affected by the effluent of an urban wastewater treatment plant. The processes of dilution and renewal in this estuary are very limited due to the geomorphology and the tidal regime, so the concentration of nutrients and chemicals are very significant.

In each of these coastal areas, water sampling was performed at several different points distributed homogeneously according to the morphology of the sampling area. A composite representative sample was constructed from the subsamples and the concentrations of the main nutrients (N, P, C and Si) were analysed (Table 1a).

Response observed and data analysis

30 min after the inoculation of the algae $(t=0)$ and after $96 \mathrm{~h}$ exposure time, biomass concentration of the treatments was measured in terms of optical density (USEPA, 2002) at a wavelength of $690 \mathrm{~nm}$ in a colorimeter adapted for direct measurements of the test vials (Nannocolor ${ }^{\circledR}$

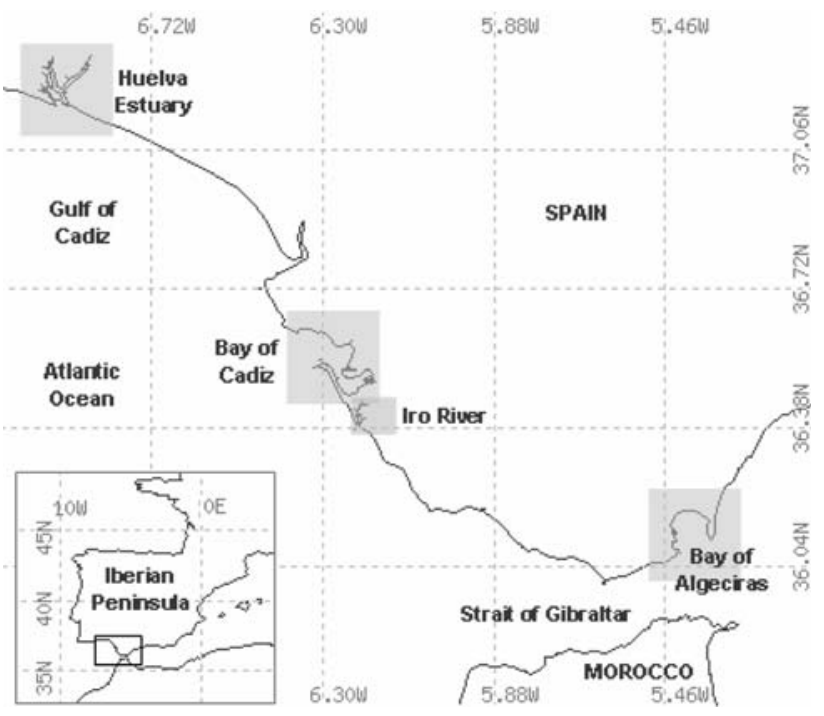

Fig. 1 Map of the location of the study zones: Huelva Estuary, Bay of Cadiz, Iro River and Bay of Algeciras

PT-3 MACHEREY-NAGEL). For the analysis of the toxicity data, net values of biomass were calculated by the following expression:

Net biomass $\left(\mathrm{B}^{\prime}\right)=$ Biomass $_{t=96} h-$ Biomass $_{t=0}$

Various statistical tests recommended in the toxicity protocols of USEPA (2002) were applied as quality control of the results. The condition of normality was determined by the Shapiro-Wilk test. The homogeneity of the variance of the triplicate has been determined by the Barlett test. For the exposure period of $96 \mathrm{~h}$, both conditions were found in all the tests. The software IcPIN provided by the USEPA (Norberg-King, 1988) was used to estimate differents $I C_{P}$ 
Table 2 Characteristics of the study zones: number of inhabitants recorded in the census in the area of study and discharges catalogued (CMAJA 1996)

\begin{tabular}{|c|c|c|c|c|c|c|}
\hline \multirow[t]{2}{*}{ Coastal zone } & \multirow{2}{*}{$\begin{array}{l}\text { Population }\left(\mathrm{N}^{\circ}\right. \\
\text { inhabitants, 2004) }\end{array}$} & \multicolumn{2}{|c|}{$\mathrm{N}^{\circ}$ Industrial discharges } & \multicolumn{2}{|c|}{$\mathrm{N}^{\circ}$ Urban discharges } & \multirow{2}{*}{$\begin{array}{l}\text { Morphology and exchange/ } \\
\text { dilution capacity }\end{array}$} \\
\hline & & $>1,000 \mathrm{~m}^{3} \mathrm{~d}^{-1}$ & $<1,000 \mathrm{~m}^{3} \mathrm{~d}^{-1}$ & $>1,000 \mathrm{~m}^{3} \mathrm{~d}^{-1}$ & $<1000 \mathrm{~m}^{3} \mathrm{~d}^{-1}$ & \\
\hline Huelva Estuary & 189.109 & 16 & 10 & 3 & 40 & $\begin{array}{l}\text { Artificial channel } \\
\text { Medium-low exchange }\end{array}$ \\
\hline Bay of Cadiz & 602.809 & 4 & 7 & 9 & 76 & $\begin{array}{l}\text { Natural bay with mean } \\
\text { depth of } 10 \mathrm{~m} \\
\text { Medium-high exchange }\end{array}$ \\
\hline River Iro & 61.028 & 0 & 1 & 0 & 12 & $\begin{array}{l}\text { Estuary under strong } \\
\text { tidal influence } \\
\text { Very low exchange }\end{array}$ \\
\hline Bay of Algeciras & 229.078 & 8 & 5 & 6 & 22 & $\begin{array}{l}\text { Natural bay with mean } \\
\text { depth of } 400 \mathrm{~m} \\
\text { High-very high exchange }\end{array}$ \\
\hline
\end{tabular}

${ }^{\mathrm{a}}$ http://www.ine.es

(and the $95 \%$ confidence range) by means of linear interpolation method.

\section{Results and discussion}

Plots in Fig. 2 show the temporal evolution of the biomass concentrations of the toxicity tests carried out in this work. SSW* graphic shows exponential growth of the controls under saturated nutrient concentrations (SC). Comparing the evolution of the treatments under both nutritive conditions for the same dilution water, it is observed that the growth rate of the tests under SC $\left(\mathrm{SSW}^{*}, \mathrm{H}^{*}, \mathrm{C}^{*}, \mathrm{I}^{*}\right.$ and $\left.\mathrm{Al}^{*}\right)$ is higher than the one under natural nutritive concentration (NC). In the same way, it is observed how both nutritive conditions undergo a lag phase during the first $24 \mathrm{~h}$ in the tests carried out with the dilution water from the Bay of Cadiz $\left(\mathrm{C}^{*}\right.$ and $\left.\mathrm{C}\right)$. In the case of the dilution waters from Iro River and Bay of Algeciras (I, I*, $\mathrm{Al}$ and $\mathrm{Al}^{*}$ ), a decrease of the populations is observed instead of the aforementioned lag phase. These phases could be due to the differences between the culture media of the inoculum (synthetic seawater + modified $f / 2$ ) and the toxicity media. Because of this, in the case of the SSW, this lag phase does not take place. This effect does not depend on the nutrient concentration as it is observed both in the enriched media (SC) and in the natural ones (NC).

The Fig. $3 \mathrm{a}$ and Table 3 show the calculated $\mathrm{IC}_{\mathrm{p}}$ concentrations of the test in standard experimental conditions $\left(\mathrm{SSW}^{*}\right) . \mathrm{IC}_{50}$ concentration is higher to $10 \mathrm{mg} / \mathrm{L}$ and it has the same order of magnitude that the one calculated by Hampel et al. (2001) for Isochrysis galbana and for others marine microalgae (Table 4). Comparing the results obtained in standard conditions $\left(\mathrm{IC}_{50}>10 \mathrm{mg} / \mathrm{L}\right)$ with the ones published for freshwater microalgae (ECETOC, 1993), it is observed that Isochrysis galbana shows a sensitivity to the LAS similar to Dunaliella primolecta and Microcystis aeroginosa, although it is more resistant than Navicula Peliculosa. Regarding other marine organisms (Table 4) and in the case of the marine crustaceans, the $\mathrm{EC}_{50}$ concentrations calculated for other authors (Painter and Zabel 1988; Liwarska-Bizukojk 2005) are higher (from 40.4 to $66 \mathrm{mg} / \mathrm{L}$ ). With respect to molluscs, Isochrysis galbana it has a similar sensibility to the ones observed by several authors. Finally, regarding the group of the marine fishes, the bibliographical data show that these fishes are more sensitive to the surfactant than the microalga.

Plots in Fig. 3 compare the calculated $\mathrm{IC}_{\mathrm{p}}$ concentrations obtained in each nutritive conditions for the different dilution waters selected in this study. It is observed that in all the tests, there are differences between the effects of the LAS on the microalga under SC and NC. In SC tests, LAS toxicity is lower. In fact, in those tests, the maximum percentage of inhibition calculated for the range of concentrations tested, did not reach $50 \%$ in any case. On the other hand, under NC conditions, it was possible to calculate the $\mathrm{IC}_{50}$ for all the dilution waters. The differences among the $\mathrm{IC}_{\mathrm{p}}$ concentrations are more noticeable insofar as the calculated effect is bigger. Thus, for all the dilutions waters, the differences between $\mathrm{IC}_{20}$ under $\mathrm{SC}$ and $\mathrm{NC}$ are higher than the ones obtained for the $\mathrm{IC}_{1}$ (Table 3). These differences are more noticeable in the tests carried out with dilution water from the Huelva Estuary (Fig. 3b) and from the Bay of Algeciras (Fig. 3e).

Regarding the $\mathrm{IC}_{20}$, for 4 out of the 5 types of dilution water (except the Bay of Cadiz, Fig. 3c) there are meaningful differences between both nutritive conditions (there is no overlapping of the confidence ranges). These 
Fig. 2 Temporal evolution of biomass during the toxicity tests
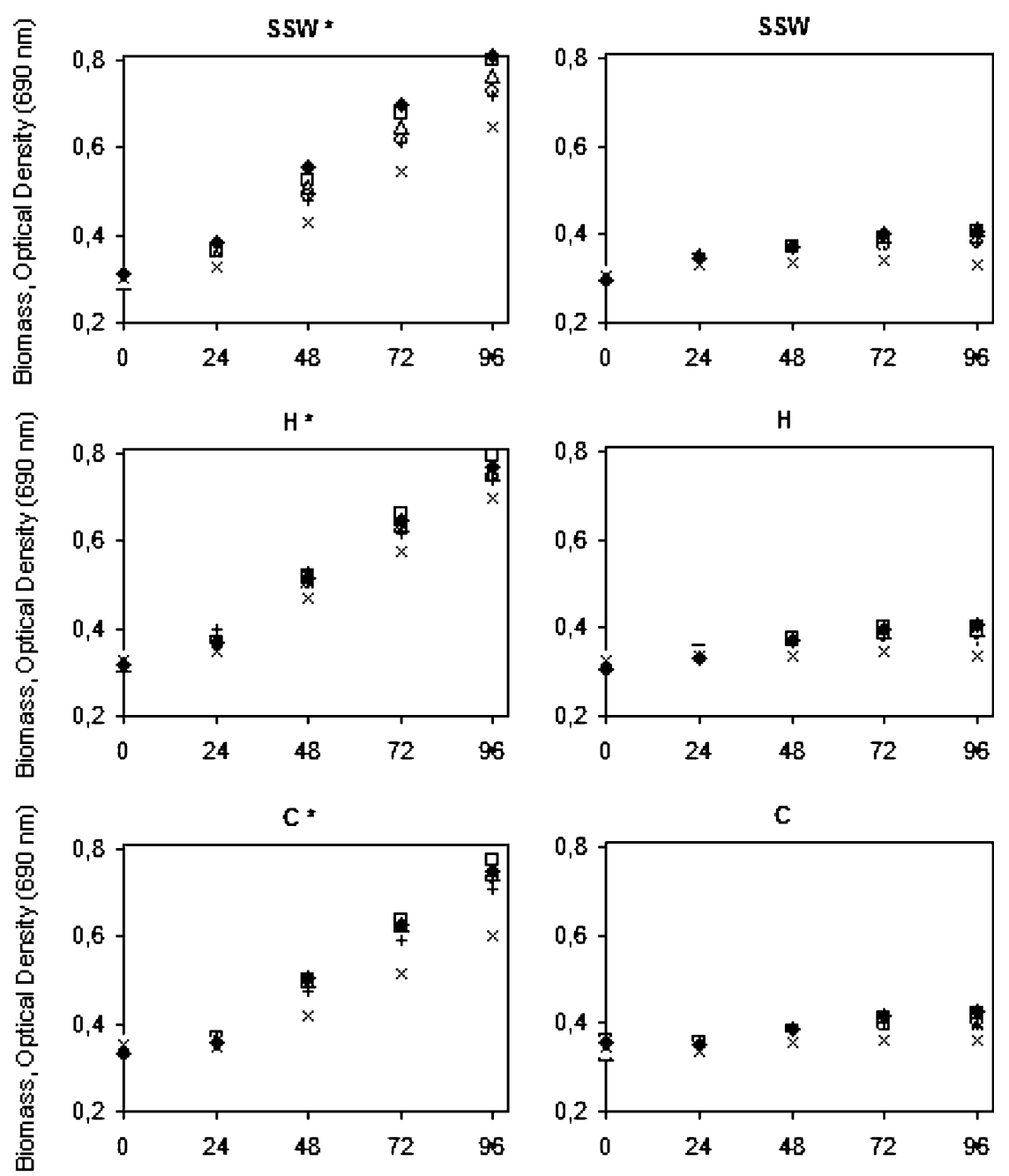

c
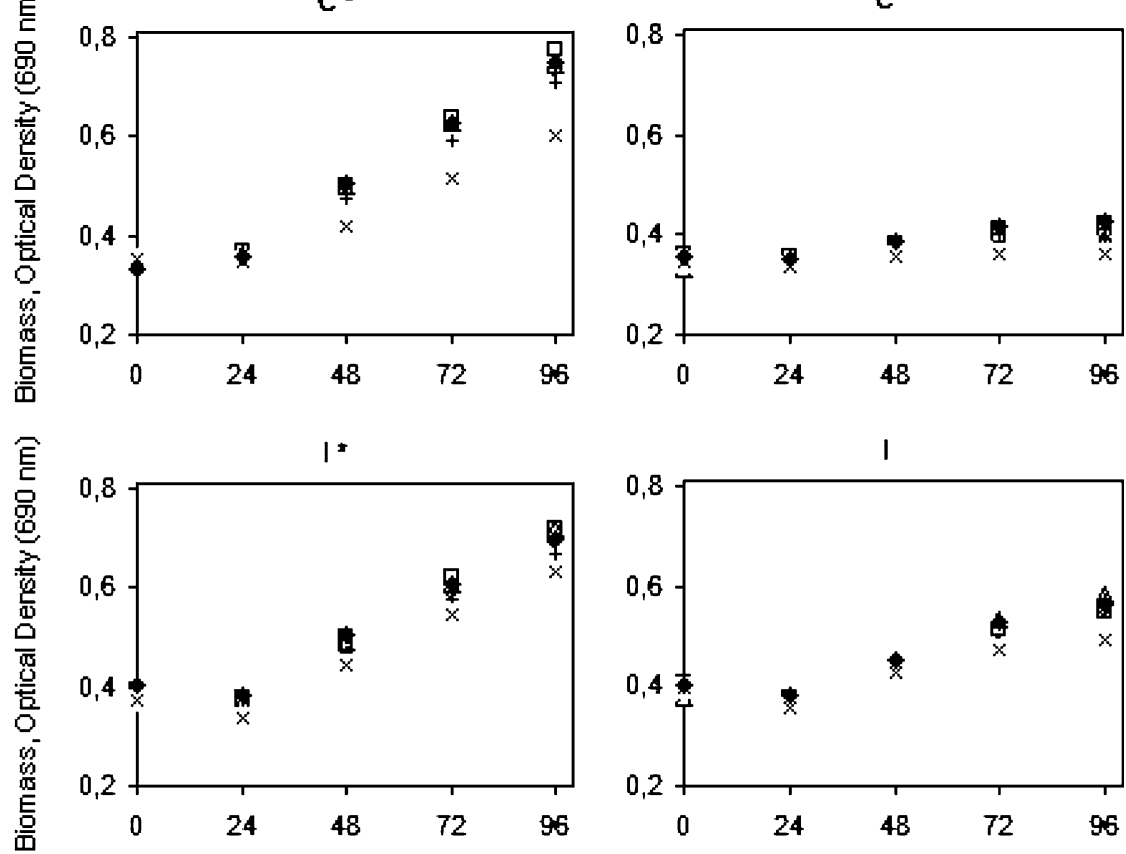

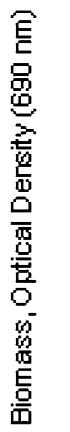
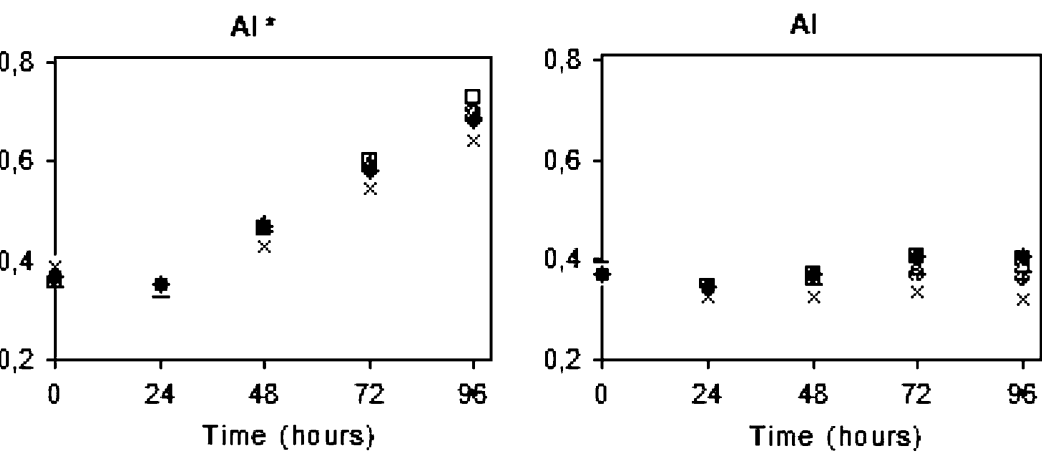

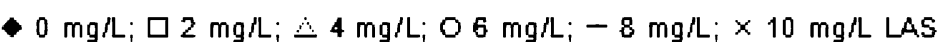



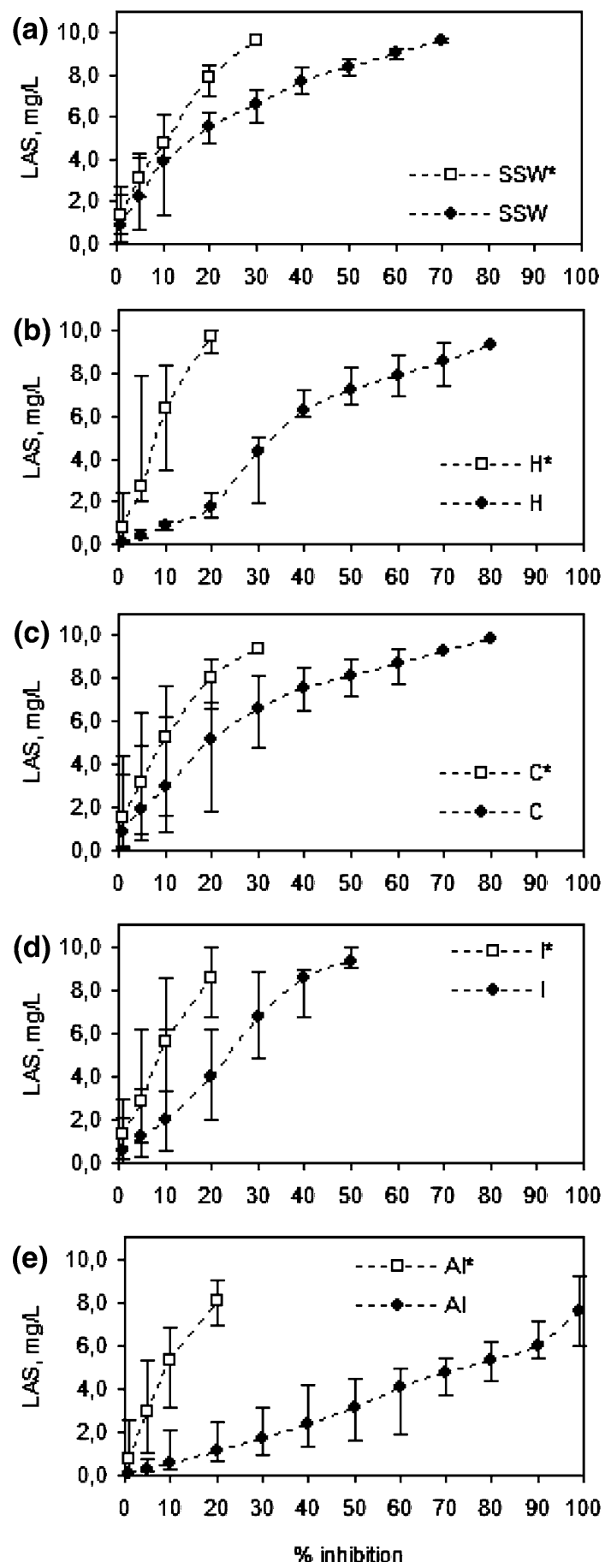

Fig. 3 Inhibition concentrations $\left(\mathrm{IC}_{\mathrm{p}}, 96-\mathrm{h}\right)$ obtained in the toxicity tests of LAS and Isochrysis galbana

differences are maximized in the tests with dilution water from the Bay of Algeciras (decrease of an $85.8 \%$ of the value of the $\mathrm{IC}_{20}$ under $\mathrm{NC}$, Fig. 3e) and they are minimized in the tests with synthetic seawater (decrease of the $30 \%$, Fig. 3a).

In SC tests, the microalgae resist the toxic effect of the LAS in better physiological conditions than when facing the toxic effect in $\mathrm{NC}$, where the alga is subjected to, at least, two sources of stress: limitation of nutrients and presence of a toxic chemical. In the case of the test in NC with dilution water from the Iro River (Fig. 3d) the alga is more resistant to LAS with respect to the other tests in NC because the higher nutrient natural concentrations in that waters (Table 1a). In terms of toxicity, the inhibition concentrations for $p \geq 50$ demonstrate that the alga is more resistance to LAS in "enriched" waters, since the alga is capable of absorbing the toxic shock in better conditions than in "more limited in nutrients" natural waters.

In order to analyse the effect of the dilution water in the toxicity of LAS, the results of the $\mathrm{IC}_{\mathrm{P}}$ calculated for the different waters employed in this work are shown separately in Fig. 4. There are no meaningful differences in the results obtained from waters of different sources under SC (Fig. 4a). However, under NC, differences are found in the results, being those obtained from the Huelva Estuary and from the Bay of Algeciras more sensible (Fig. 4b).

Table 2 summarises the data of urban and industrial activities in the origin areas of the dilution waters. The Huelva Estuary and the Bay of Algeciras are highly populated areas with a strong urban and industrial activity. Nowadays both zones are considered as the most anthropized areas in southern Spain. Pollutants loadings and the wide range of chemicals that reach the environmental waters throughout the discharges are very high. Thus, the differences obtained in the tests of these waters under NC could be due to the joint (synergic) action with other chemicals and LAS, as described in some works (Abel and Axiak 1991; Broderius et al. 1995; Jensen and Sverdrup 2002). In those cases, it should be necessary to carry out a whole characterization of the main pollutants present in those waters with the aim to obtain more concrete conclusions.

Two of the main applications of the algal toxicity tests are the environmental risk assessment (ERA) of chemicals in waters (e.g., in European Union: EEC 1993, EEC 1996) and the derivation of environmental quality criteria (e.g., in European Union: EEC 2000). In the case of the ERA, the parameter used for the determination of the PNEC (predicted no-effect concentration) is the NOEC (no-observed effect concentration). As seen in this work, insofar as the inhibition percentage diminishes, the differences between the dilution waters and the nutritive conditions are minimized. Thus, the usage of the NOEC obtained from the algal toxicity tests in standard conditions $\left(\mathrm{SSW}^{*}\right)$ can be extrapolated to the environment. But, in the procedure for deriving environmental quality criteria, it is possible to use the $\mathrm{IC}_{50}$ in the calculation procedure. In this case, toxicity test with microalgae carried out in standard experimental conditions could underestimate the toxicity found in natural conditions. 
Table $3 \mathrm{IC}_{1}, \mathrm{IC}_{20}, \mathrm{IC}_{50}$ and $95 \%$ confidence ranges (min. and max.) (mg/L, LAS) obtained in the toxicity tests of $I$. galbana exposed to different concentrations of LAS at $96 \mathrm{~h}$

\begin{tabular}{|c|c|c|c|c|c|c|}
\hline & \multicolumn{2}{|l|}{$\mathrm{IC}_{1}$} & \multicolumn{2}{|l|}{$\mathrm{IC}_{20}$} & \multicolumn{2}{|l|}{$\mathrm{IC}_{50}$} \\
\hline & $\mathrm{SC}$ & $\mathrm{NC}$ & $\mathrm{SC}$ & $\mathrm{NC}$ & $\mathrm{SC}$ & $\mathrm{NC}$ \\
\hline Synthetic seawater & $\begin{array}{l}1.34 \\
(0.45-2.34)\end{array}$ & $\begin{array}{l}0.83 \\
(0.13-2.68)\end{array}$ & $\begin{array}{l}7.91 \\
(7.02-8.43)\end{array}$ & $\begin{array}{l}5.54 \\
(4.81-6.24)\end{array}$ & $<10$ & $\begin{array}{l}8.41 \\
(7.94-8.79)\end{array}$ \\
\hline Huelva Estuary & $\begin{array}{l}0.75 \\
(0.24-2.40)\end{array}$ & $\begin{array}{l}0.08 \\
(0.07-0.11)\end{array}$ & $\begin{array}{l}9.76 \\
(8.99-10.00)\end{array}$ & $\begin{array}{l}1.73 \\
(1.25-2.37)\end{array}$ & $<10$ & $\begin{array}{l}7.25 \\
(6.56-8.34)\end{array}$ \\
\hline Bay of Cadiz & $\begin{array}{l}1.54 \\
(0.16-4.42)\end{array}$ & $\begin{array}{l}0.85 \\
(0.09-3.53)\end{array}$ & $\begin{array}{l}8.07 \\
(6.60-8.93)\end{array}$ & $\begin{array}{l}5.20 \\
(1.83-6.90)\end{array}$ & $<10$ & $\begin{array}{l}8.13 \\
(7.16-8.91)\end{array}$ \\
\hline Iro River & $\begin{array}{l}1.30 \\
(0.18-2.92)\end{array}$ & $\begin{array}{l}0.58 \\
(0.01-2.13)\end{array}$ & $\begin{array}{l}8.57 \\
(6.78-9.98)\end{array}$ & $\begin{array}{l}3.95 \\
(1.99-6.21)\end{array}$ & $<10$ & $\begin{array}{l}9.26 \\
(8.98-9.99)\end{array}$ \\
\hline Bay of Algeciras & $\begin{array}{l}0.73 \\
(0.21-2.53)\end{array}$ & $\begin{array}{l}0.07 \\
(0.03-0.19)\end{array}$ & $\begin{array}{l}8.09 \\
(6.95-9.03)\end{array}$ & $\begin{array}{l}1.15 \\
(0.64-2.46)\end{array}$ & $<10$ & $\begin{array}{l}3.15 \\
(1.58-4.49)\end{array}$ \\
\hline
\end{tabular}

Table $4 \mathrm{EC}_{50} / \mathrm{IC}_{50}$ concentrations for LAS in some groups of aquatic species

\begin{tabular}{|c|c|c|c|c|}
\hline Species & Type of water & Exposure Time (h) & LAS (mg/L) & Reference \\
\hline \multicolumn{5}{|l|}{ Microalga } \\
\hline Rhodomonas salina & Saltwater & 72 & $\mathrm{C}_{11}(4.43) ; \mathrm{C}_{13}(0.36)$ & Hampel et al. (2001) \\
\hline Isochrysis aff. Galbana & Saltwater & 72 & $\mathrm{C}_{11}(7.70) ; \mathrm{C}_{13}(0.53)$ & Hampel et al. (2001) \\
\hline Tetraselmis suecica & Saltwater & 72 & $\mathrm{C}_{11}(13.37) ; \mathrm{C}_{13}(1.23)$ & Hampel et al. (2001) \\
\hline Nannochloropsis gaditana & Saltwater & 72 & $\mathrm{C}_{11}(1.38) ; \mathrm{C}_{13}(0.18)$ & Hampel et al. (2001) \\
\hline Dunaliella primolecta & Freshwater & 48 & 8.62 & ECETOC $(1993)^{a}$ \\
\hline Microcystis aeroginosa & Freshwater & 96 & 5.0 & ECETOC $(1993)^{\mathrm{a}}$ \\
\hline Navícula Peliculosa & Freshwater & 96 & 1.4 & ECETOC $(1993)^{\mathrm{a}}$ \\
\hline \multicolumn{5}{|l|}{ Crustacean } \\
\hline Mysidopsis bahia & Saltwater & 96 & 1,420 & Painter and Zabel (1988) \\
\hline Penaeus duororum & Saltwater & 96 & 66 & Painter and Zabel (1988) \\
\hline Artemia salina & Saltwater & 24 & 40.4 & Liwarska-Bizukojc (2005) \\
\hline Acartia tonsa & Saltwater & 48 & 1.11 & Christoffersen et al. (2003) \\
\hline \multicolumn{5}{|l|}{ Mollusc } \\
\hline Crassostrea sp. & Saltwater & 48 & 7.4 & Painter and Zabel (1988) \\
\hline Tapes phillippinarum & Saltwater & 96 & 10.5 & ECETOC $(1993)^{\mathrm{a}}$ \\
\hline Physa acuta & Saltwater & 24 & 16.65 & Liwarska-Bizukojc (2005) \\
\hline \multicolumn{5}{|l|}{ Fish } \\
\hline Gadus morhua & Saltwater & 96 & 1 & Swedmark et al. (1971) \\
\hline Pleuronectes flesus & Saltwater & 96 & 1.5 & Swedmark et al. (1971) \\
\hline Pleuronectes platessa & Saltwater & 96 & 1 & Swedmark et al. (1971) \\
\hline Pomatochistus microps & Saltwater & 96 & 2.6 & ECETOC $(1993)^{\mathrm{a}}$ \\
\hline Sparus aurata (embryos) & Saltwater & 24 & $0.1-7.7(2.25, n=6)$ & Hampel et al. (2001) \\
\hline
\end{tabular}

${ }^{a}$ Data obtained from the ECETOC toxicity database

Species with two or more references, range of $\mathrm{EC}_{50}$ (average and $\mathrm{N}^{\circ}$ of data) is included

\section{Conclusions}

In this paper, results of LAS toxicity were obtained on the marine microalga Isochrysis galbana in standard experimental conditions and in variable conditions of nutrients and dilution water. The results obtained indicate that the composition and the nutritive conditions of the test medium are determining factors in the determination of the $\mathrm{IC}_{50}$ of LAS in Isochrysis galbana. The alga is more sensible in nutrient natural concentrations and in seawaters from polluted zones. 
Tests in saturated nutrient concentrations (SC)

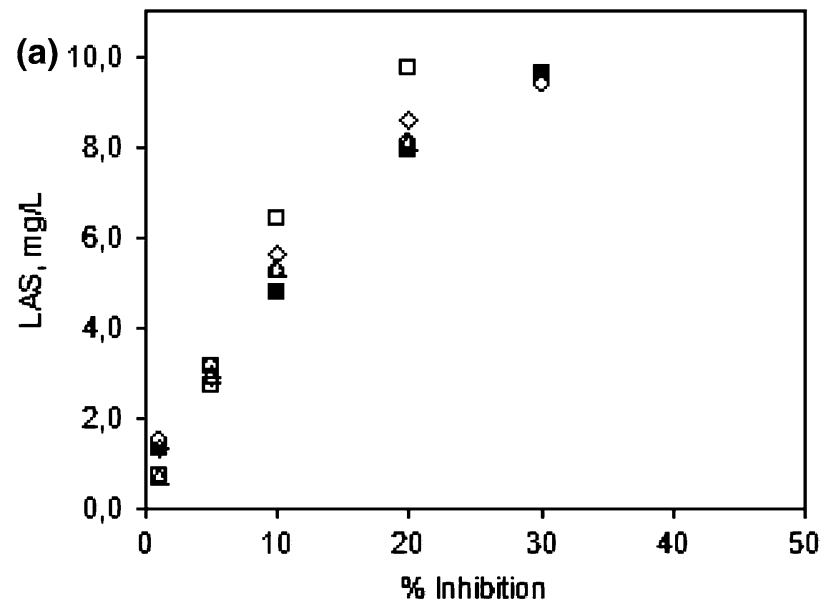

Tests in natural nutrient concentrations (NC)

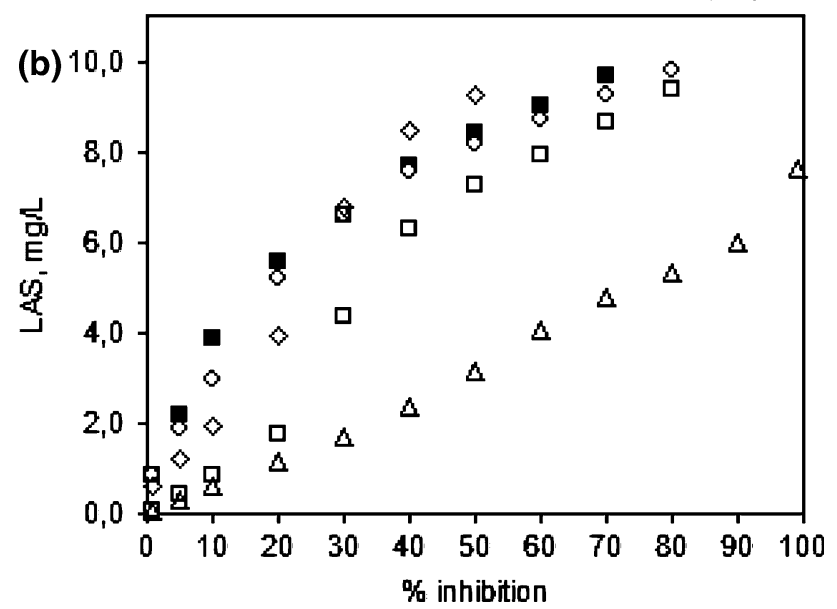

Fig. 4 Inhibition concentrations ( $\left.\mathrm{IC}_{\mathrm{p}}, 96-\mathrm{h}\right)$ obtained in the tests under satured nutrient concentration (SC) and natural nutrient concentration (NC). $\square-$ Synthetic seawater (SSW); $\square$-Huelva Estuary (H); $\bigcirc$-Bay of Cadiz (C); $\diamond$-Iro River (I); $\Delta$-Bay of Algeciras (Al)

Finally, and according to the particular results obtained in this work, it is advisable to carry out new toxicity tests with other chemicals on different microalga species and test media in order to obtain general conclusions about the extrapolation of toxicity results with microalga to the environment.

Acknowledgments The authors thank Dr. Luis Lubian (ICMANCSIC, Spain), for providing cultures of Isochrysis galbana and to the Regional Council of Environment of Andalusia (Consejeria de Medio Ambiente) of Spain for financing this study.

\section{References}

Abel PD, Axiak V (1991) Ecotoxicology and the marine environment. Ellis Horwood, England
Broderius SJ, Kahl M, Hoglund MD (1995) Use of joint toxic response to define the primary mode of action for diverse industrial organic chemicals. Environ Toxicol Chem 14:15911605

Campa-Córdova AI, Luna-Gonzalez A, Ascencio F, Cortés-Jacinto E, Cáceres-Martínez CJ (2006) Effects of chloramphenicol, erythromycin and furazolidone on growth of Isochrysis galbana and Chaetoceros gracilis. Aquaculture 260:145-150

Cavalli L, Clerici R, Radici P, Valtorta L (1999) Update on LAB/ LAS. Tenside Surf Det 36:254-258

Cavalli L, Cassani G, Vigano L, Pravettoni S, Nucci G, Lazzarin M, Zatta A (2000) Surfactants in sediments. Tenside Surf Det $37: 282-288$

Christoffersen K, Hansen BW, Johansson LS, Krog E (2003) Influence of LAS on marine calanoid copepod population dynamics and potential reproduction. Aquat Toxicol 63:405-416

CMAJA, Consejería de Medio Ambiente, Junta de Andalucía (1996) Inventario de vertidos líquidos al litoral de Andalucía. Sevilla, Spain

Correa-Reyes G, Viana MT, Marquez-Rocha FJ, Licea AF, Ponce E, Vazquez-Duhalt R (2007) Nonylphenol algal bioaccumulation and its effect through the trophic chain. Chemosphere 68:662670

ECETOC, European Centre for Ecotoxicology, Toxicology of Chemicals (1993) Technical report $\mathrm{N}^{\circ}$ 56. Aquatic toxicity data evaluation. Appendix C: the database. ECETOC, Brussels, Belgium

ECETOC, European Centre for Ecotoxicology, Toxicology of Chemicals (2001) Technical report $N^{\circ} 82$. Risk assessment in marine environments. ECETOC, Brussels, Belgium

EEC, European Economic Community (1993) Council Regulation (EEC) $\mathrm{N}^{\circ} 793 / 93$, of 23 March 1993, on the evaluation and control of the risks of existing substances. Official Journal, L 84/ 1, of 5 April 1993

EEC, European Economic Community (1996) Technical guidance document in support of commission directive 96/67/EEC on risk assessment for new notified substances and commission regulation EC $\mathrm{N}^{\circ} 1488 / 94$ on risk assessment for existing substances. Office for Official Publications of the European Communities, Luxembourg

EEC, European Economic Community (2000) Directive 2000/60/CE of the European Parliament and of the Council, of 23 October 2000, establishing a frame work for Community action in the field of water policy. Official Journal, L 327/1, of 22 December 2000

Garrido-Pérez C, Acevedo-Merino A, Nebot-Sanz E, Sales-Marquez D (2003) A set of marine microalgae biotests for the evaluation of biological water quality in enclosure areas in south of Spain. Water Sci Technol 47(9):85-92

González S, Petrovic M, Barcelo D (2007) Removal of a broad range of surfactants from municipal wastewater. Comparison between membrane bioreactor and convenctional activated sludge treatment. Chemosphere 67:335-343

Guillard RRL, Ryther JH (1962) Studies on marine planktonic diatoms, I. Cyclotella nana Hustedt and Dentonula confervaceae Cleve Gran. Can J Microbiol 8:229-239

Hampel M, Moreno-Garrido I, Sobrino C, Lubián LM, Blasco J (2001) Acute toxicity of LAS in marine microalgae: Esterase activity and inhibition growth as endpoints of toxicity. Ecotox Environ Safe 48:287-292

HERA (Human and Environmental Risk Assessment) (2004) LAS CAS No 68411-30-3. Version No. 9. (http://www.heraproject.com). A.I.S.E. Association Internationale de la Savonnerie, de la Détergence et des Produits d'Entretien (http://www.aise-net.org), Cefic. European Chemical Industry Council (http://www.cefic.org)

Huertas E, Montero O, Lubian LM (2000) Effects of dissolved inorganic carbon availability on growth, nutrient uptake and 
chlorophyll fluorescent of two species of marine microalgae. Aquacult Eng 22:181-197

Jensen J, Sverdrup LE (2002) Joint toxicity of linear alkylbencene sulfonates and pyrene on Folsomia fimetaria. Ecotox Environ Safe 52:75-81

Lara-Martín PA, Petrovic M, Gómez-Parra A, Barceló D, GonzálezMazo E (2006) Presence of surfactants and their degradation intermediates in sediment cores and grabs from the Cadiz Bay area. Environ Pollut 144:483-491

León VM, Sáez M, González-Mazo E, Gómez-Parra A (2002) Occurrence and distribution of linear alkylbenzene sulfonates and sulfophenylcarboxylic acids in several Iberian Littoral ecosystems. Sci Total Environ 288:215-226

Liwarska-Bizukojc E, Miksch K, Malachowska-Jutsz A, Kalka J (2005) Acute toxicity and genotoxicity of five selected anionic and nonionic surfactants. Chemosphere 58:1249-1253

Lubián LM, Yúfera M (1989) Colección de Cepas de Microalgas del Instituto de Ciencias Marinas de Andalucía CSIC. Acuicultura intermareal, Instituto de Ciencias Marinas de Andalucía, CSIC, Cádiz, Spain

Matthijs E, Holt MS, Kiewiet A, Rijs GBJ (1999) Environmental Monitoring for Linear Alkylbenzene Sulphonate (LAS), Alcohol Ethoxylate (AE), Alcohol Ethoxy Sulphate (AES), Alcohol Sulphate (AS) and Soap. Environ Toxicol Chem 18:2634-2644

Moreno-Garrido I, Lubian LM, Soares AMVM (2000) Influence of cellular density on determination of $\mathrm{EC}_{50}$ in microalgal growth inhibition tests. Ecotox Environ Safe 47:112-116

Norberg-King TJ (1988) An interpolation estimate for chronic toxicity: the $\mathrm{IC}_{\mathrm{p}}$ approach. NETAC technical report 05-88. United States Environmental Protection Agency, Duluth, MN

Painter H, Zabel T (1988) Review of the environmental safety of LAS. Technical report CO 1659-M/EV 8658. Water Research Center. Medmenham, United Kingdom

Ramamoorthy R, Baddaloo EG (1995) Handbook of chemical toxicity profiles of biological species, vol I: Aquatic Species. CRC Press, Inc
Rand GM (ed) (1995) Fundamentals of aquatic toxicology. Effects, environmental fate, and risk assessment, 2nd edn. Ed. Taylor \& Francis, Washington

Roberts DW (2003) Optimisation of the linear alkylbenzene sulfonation process for surfactant manufacture. Org Proc Res Dev 7:172-194

Sanz JL, Culubret E, de Ferrer J, Moreno A, Berna JL (2003) Anaerobic biodegradation of linear alkylbenzene sulfonate (LAS) in upflow anaerobic sludge blanket (UASB) reactors. Biodegradation 14:57-64

Satoh A, Vudikaria LQ, Kurano N, Miyachi S (2005) Evaluation of the sensitivity of marine microalgal strains to the heavy metals, $\mathrm{Cu}, \mathrm{As}, \mathrm{Sb}, \mathrm{Pb}$ and $\mathrm{Cd}$. Environ Int 31:713-722

Swedmark M, Braten B, Emanuesson E, Granmo A (1971) Biological effects of surface-active agents on marine animals. Marine Biol 9:183-201

Tsvetnenko Y, Evans L (2002) Improved approaches to ecotoxicity testing of petroleum products. Mar Poll Bull 45:148-156

Tzovenis I, Triantphyllidis G, Naihong X, Chatzinikolaou E, Papadopoulou K, Xouri G, Tafas T (2004) Cryopreservation of marine microalgae and potential toxicity of cryoprotectants to the primary steps of the aquaculture food chain. Aquaculture 230:457-473

USEPA, United States Environmental Protection Agency (2002) Shortterm methods for estimating the chronic toxicity of effluents and receiving waters to freshwater organisms, 4th edn. EPA-821-R02-013. USEPA, Office of Water, Washington, DC

Weiner JA, De Lorenzo ME, Fulton MH (2004) Relationship between uptake capacity and differential toxicity of the herbicide atrazine in selected microalgal species. Aqua Toxicol 68:121-128

Yap CK, Ismail A, Omar H, Tan SG (2004) Toxicities and tolerances of $\mathrm{Cd}, \mathrm{Cu}, \mathrm{Pb}$ and $\mathrm{Zn}$ in a primary producer (Isochrysis galbana) and in a primary consumer consumer (Perna viridis). Environ Int 29:1097-1104

Ying G (2006) Fate, behaviour and effects of surfactants and their degradation products in the environment. Environ Int 32:417-431 